\title{
Ionos tenzidek adszorpciója oldataik felszínén
}

\author{
GILÁNYI Tibor \\ ELTE TTK, Fizikai Kémiai Tanszék, Pázmány Péter sétány 1/A. 1117, Budapest, Magyarország
}

\section{Bevezetés}

Az adszorpciónak alapvető jelentősége van a határfelületek tulajdonságainak módosításában, ezért a kolloid rendszerek stabilitásában is meghatározó szerepet játszik. A téma rendkívül széleskörü gyakorlati fontossága azt eredményezte, hogy az adszorpció kísérletes és elméleti kutatásának a klasszikusoktól napjainkig óriási irodalma keletkezett. Az 1980-as években már mintegy évi 200 közlemény jelent meg a témakörben. Ennek ellenére több kérdés mindmáig tisztázatlan maradt. A nagy mennyiségü irodalom azonban nem feltétlenül segíti az eredményekben az eligazodást, hanem ellenkezőleg, a számos hibás kísérlet és interpretáció, valamint megalapozatlan elmélet publikációja nehezíti azt. Példaként minderre érdemes az egyik legjelentősebb folyóiratban jelenleg megjelent gyöngyszemet idézni, mely szerint Gibbs határfelületi termodinamikája „egy elfogadott dogma” (,accepted dogma") ${ }^{1}$. Mivel a minősítést nem támasztja alá tudományos érvelés, az nyilván egy „,ogma” cáfolata kinyilatkoztatással a 21. században.

Az adszorpció szempontjából a legfontosabb anyagok a tenzidek (felületaktív anyagok). Vizes oldatok esetében a tenzidek adszorpciójának hajtóereje az úgynevezett „hidrofób” kölcsönhatás, melynek során a határfelületi tartományban a tenzid hidrofób része részben vagy teljesen kizáródik a vizes közegből. Jelen munkában az ionos tenzidek vizes oldatainak szabad felszínén lejátszódó adszorpcióját tanulmányozzuk a leggyakrabban használt módszerrel, a felületi feszültség koncentrációjának mérésével a Gibbs-féle határfelületi termodinamika felhasználásával. A kísérletes munka célja felhívni a figyelmet a mérések értékelésében elkövetett hibákra, valamint kidolgozni egy új adszorpciós izoterma-egyenletet.

\section{Vizsgált rendszerek és alkalmazott módszerek}

A tenzideket szulfonálással állítottuk elö ${ }^{2}$ a megfelelö alkoholokból. A reakcióelegy semlegesítése alkáli hidroxiddal történt. Szintetizáltuk az alkilszulfát nátrium sójának homológ sorát $(\mathrm{n}=8,910,11,12,13,14)$, valamint a decilszulfát alkáli sóit ( $\mathrm{Li}, \mathrm{Na}, \mathrm{K}, \mathrm{Rb}, \mathrm{Cs}$ ). A tenzideket forró benzol-etanol 1:1 elegyéből átkristályosítottuk. Az előállított modellek a homológok vonatkozásában gázkromatográfiás tisztaságúak. A tenzidekből „felületi tisztaságú" minőségben készítettünk a mérésekhez oldatokat (lásd később).
A felületi feszültséget Wilhelmy-lemez módszerrel, időfüggését függőcsepp módszerrel határoztuk meg 25,0 $\pm 0,1{ }^{\circ} \mathrm{C}$-on. Meg kell itt említeni, hogy 1916-ban Harkins a felületi feszültség méréseket a hibák komédiájaként („,comedy of errors”) minősítette. A minősítés a méréstechnikákra és értékelésükre vonatkozott, azonban az igazi komédia csak később következett és tart napjainkban is, amint azt megmutatjuk. Sajnálatos, hogy a tankönyvekben és a Wikipédiában maga a felületi feszültség is hibásan van definiálva a felületre merőleges erővel, holott ez az erő a felület síkjában hat.

A mérések értékelése Gibbs adszorpciós egyenlete alapján történt:

$$
-d \sigma=\sum \Gamma_{i} d \mu_{i}
$$

melyben $\sigma$ a felületi feszültség, $\mu_{i}$ az $i$-ik komponens kémiai potenciálja és $\Gamma_{i}$ az adszorpciós többletmennyiség. $\Gamma_{i}$ értéke függ a Gibbs-féle megosztó felület helyzetétől. Az erős elektrolit típusú ionos tenzidek kétkomponensű vizes oldataira alkalmazva az 1. egyenletet, továbbá bevezetve a vízre vonatkoztatott Gibbs-féle relatív többletmennyiséget (a fázisokat elválasztó felület helyzetét a $\Gamma_{v i z}=0$ feltételnek megfelelően választva)

$$
\Gamma=-\frac{1}{2 R T}\left(\frac{\partial \sigma}{\partial \ln \left(\gamma_{ \pm} c\right)}\right)
$$

ahol $\Gamma$ a tenzid relatív adszorpciós többlete, $\gamma_{ \pm}$és $c$ a tenzid átlagos aktivitási koefficiense illetve koncentrációja az oldatban. Az aktivitási koefficienseket a Debye-Hückel elmélettel számoltuk.

A 2. egyenlet korrekt alkalmazásához három feltételnek teljesülni kell: a/ termodinamikai egyensúlyban kell lennie a rendszernek, b/ az oldatnak kétkomponensünek kell lennie és c/ a tenzid koncentrációjának kisebbnek kell lennie a kritikus micellaképződési koncentrációnál $(c<c m c)$.

Az a/ feltétel megköveteli, hogy a felületi feszültség időben állandó legyen. Az 1. ábrán példaként az átkristályosítással tisztított tenzidekből készült oldat felületi feszültségének tipikus időfüggését mutatjuk be (alsó görbe). Az időfüggés nem értelmezhető az adszorpció diffúziós kinetikája alapján, ezért feltételezték, hogy a tenzidnek az adszorpciós rétegbe való belépéséhez kinetikai gátat kell legyőznie. Ezek az elméletek feleslegesnek bizonyultak a b/ pontban szereplö feltételt megvizsgálva. 


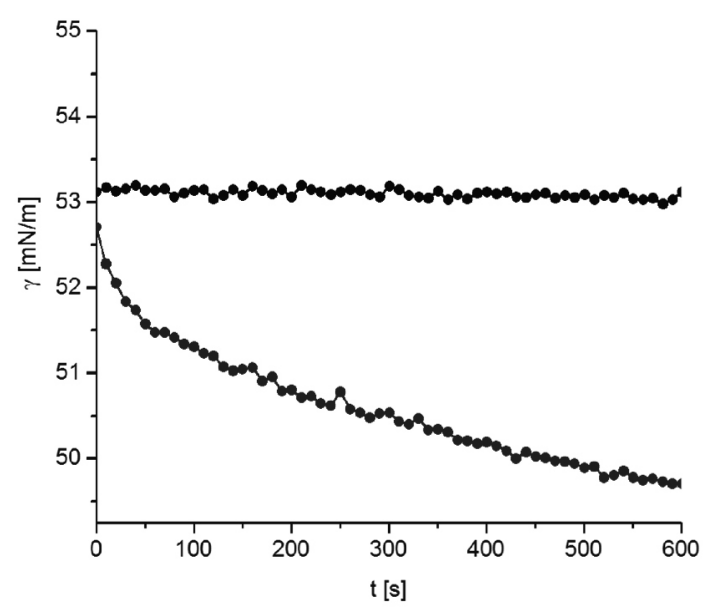

1. Ábra: A felületi feszültség időfüggése (4 mM-os Merck nátrium dodecilszulfát oldata felületi tisztítás előtt (alsó görbe) és gázdiszperziós módszerrel tisztítva (felső görbe)).

Komponensként kell kezelni azokat a mintákban előforduló szennyezéseket, melyek a felületi feszültséget mérhető mértékben befolyásolják. Ebből a szempontból a szintézisből visszamaradó alkoholok (esetleg homológok) jelentenek problémát. Az alkoholok felületaktivitása csaknem két nagyságrenddel nagyobb az azonos alkilláncú ionos tenzidekénél, ami azt eredményezi, hogy már nyomnyi mennyisében sem lehet azokat figyelmen kívül hagyni. Mysels mutatta meg elsőként ${ }^{3}$, hogy a fizikai tisztítási módszerek (átkristályosítás, éteres extrakció) nem elég hatékonyak a szennyezések eltávolításához. Mysels a Wilhelmy-lemez módszerrel történő mérés közben buborékokat képezett az oldatban egy kapilláris segítségével. A buborékoltatás során a felületi feszültség folyamatosan növekedett. A módszer azon alapul, hogy az említett szennyezések a buborékok felületén feldúsulnak és a buborékokkal együtt eltávolíthatók. Mysels tisztítási megoldása hosszadalmas és nehézkes, ezért hatékonyabb módszereket vezettünk be (haboztatás ${ }^{4}$, gázdiszperziós módszer ${ }^{5}$ ).

A gázdiszperziós módszerrel tisztított oldat felületi feszültségének időfüggése (felső görbe az 1. ábrán) a vizsgált időtartományban megszünik. A „felületi tisztítási” módszer alkalmazása nélkül mért időfüggés a szennyezések felülethez történő lassú diffúziójának tulajdonítható. A gyakorlatban a $\sigma(c)$ függvény mérése legtöbbször szennyezett rendszereken történik a használt módszerre jellemző, általában a felület létrehozását követően néhány perc múlva. Igényesebb esetben a végtelen időre extrapolált „egyensúlyi” ó értékeket használják. Nyilvánvaló, hogy mindkét eljárás esetében hibás a kettőnél többkomponensü rendszerekre a 2. egyenlet alkalmazása, ami a teljes klasszikus irodalomra és a mérések túlnyomó többségére napjainkban is jellemző.

\section{Eredmények és tárgyalás}

A 2. ábrán a „felületi tisztaságú” tenzidek homológ sorának felületi feszültségét ábrázoltuk a tenzid koncentrációjának logaritmusa függvényében. A $\sigma(\log c)$ függvények szabályosan tolódnak el az alkillánc hosszának változásával, ami nem egyezik az irodalomban elfogadott páros-páratlan ${ }^{6}$ („odd-even effect”) csoportosítással, miszerint a páros és páratlan szénatomszámú tenzidek $\sigma(\log c)$ függvényei egymástól szisztematikusan eltolódnak. A páros-páratlan effektusra adott eröltetett elméleti értelmezések szintén feleslegesek, mert valószínűleg szennyezett rendszerekre vonatkoznak. A homológok józan várakozásnak megfelelő szabályos viselkedését viszont nem kell magyarázni.

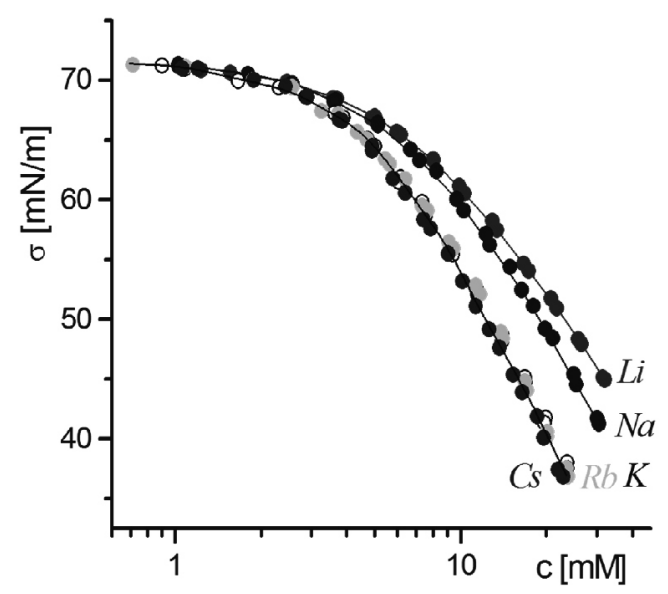

2. Ábra. A nátrium alkilszulfát homológok felületi feszültsége a koncentráció függvényében $(c<c m c)$.

A 3. ábrán a decilszulfát alkáli sók oldatainak felületi feszültsége szerepel a koncentráció függvényében. Az alkáli sók sorában a $\mathrm{Li}, \mathrm{Na}$ és $\mathrm{K}$ ellenionok esetében a ó függvények nagymértékben különböznek, a $\mathrm{K}, \mathrm{Rb}$ Cs sók viszont a kísérleti hibahatáron belül azonosak. Ezek az eredmények nem felelnek meg annak a várakozásnak, hogy az egyértékü ellenionok kémiai minősége nem játszik szerepet az ionos tenzidek adszorpciójában, ha az adszorpció hajtóereje csupán az alkilláncok kizáródása a vizes fázisból.

A 4. ábrán a 2. összefüggéssel számolt adszorpciós izotermákat tüntettük fel. Az izotermák az ideális (Langmuir) típusú telítési görbéktől különböznek. Az adszorpció egy kezdeti koncentráció tartományban „gyorsul”, majd $\Gamma$ egy szük tartományában telítési típusú függvénybe megy át mindegyik tenzid homológ esetében.

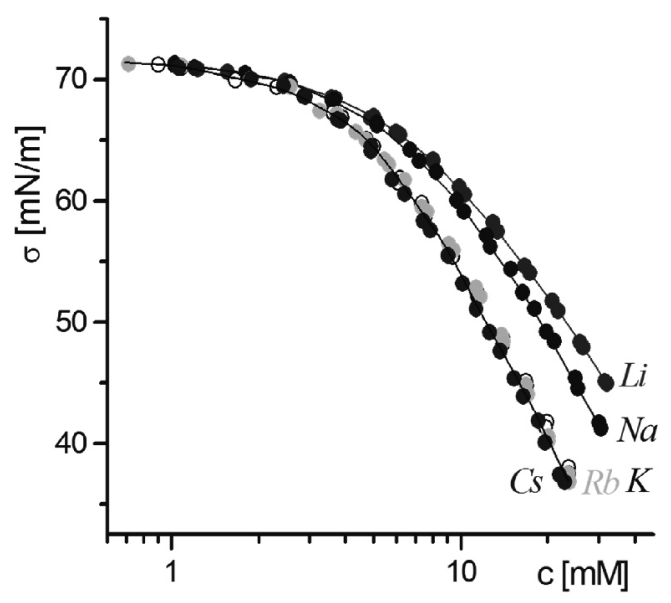

3. Ábra. A lítium-, nátrium-, kálium-, rubídium- és cézium decilszulfát felületi feszültsége a koncentráció függvényében. 


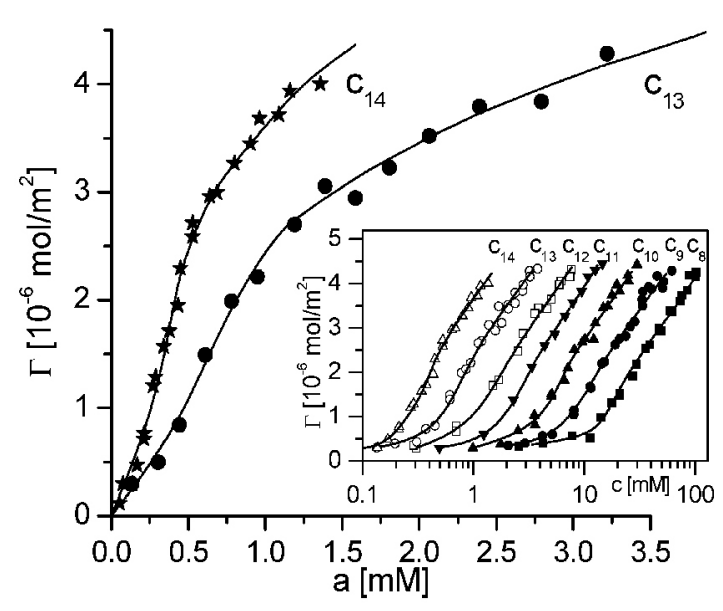

4. Ábra. A nátrium alkilszulfát homológok adszorpciós izotermája a tenzid aktivitása függvényében. A beszúrt ábrában logaritmikus koncentráció szerepel.

A 2-4. ábrán feltüntetett mérési eredmények értelmezéséhez elméleti adszorpciós izoterma-egyenlet szükséges. Az irodalomban szereplö számos elmélet közötti könnyebb eligazodás érdekében monoréteges adszorpciót feltételezve a monoréteg szabadenergiáját formálisan az alábbi alakban írjuk fel:

$$
F^{m}=N^{m} \mu^{o, m}+f(\Theta)-T S^{m}+F_{e l}
$$

melyben a felső index az $\mathrm{N}$ darab tenzid ionból képződött monoréteget jelenti. $\mu^{o, m}$ a standard kémiai potenciál, a jobboldal második tagja az adszorbeált tenzidek közötti kölcsönhatást, a harmadik tag a konfigurációs szabadenergiát és az utolsó az elektromos szabadenergiát reprezentálja. Az $f(\Theta)$ energiatagban $\Theta$ a relatív borítottságot jelenti. Az izoterma-egyenlet levezetéséhez az egyes tagokat megfelelő modellek alapján ki kell fejteni, esetleg azokból elhanyagolni. A kölcsönhatási és elektromos tag elhagyásával az ,ideális” adszorpcióra vonatkozó Langmuir egyenletet kapjuk. A kölcsönhatási tag legegyszerübb leírása a Frumkin-féle párkölcsöhatási modell ${ }^{7}$. Ezeknek a „pszeudo-nemionos” izotermáknak azonban ionok adszorpciója esetén nincs fizikai realitása. A legnagyobb nehézséget az elektromos tag modellezése jelenti. Ez történhet a fém-oldat határfelület leírására levezetett Goüy-Chapman közelítéssel ${ }^{8,9}$, vagy annak módosításával, figyelembe véve, hogy az ionok nem pontszerüek és csak a hidratált ionok sugarának megfelelő távolságig közelíthetik meg a felszínt ${ }^{10}$. Figyelembe kell venni azt is a modellek pontosítása érdekében, hogy az adszorbeált tenzidek ionos csoportja - ellentétben a fémfelszín töltésével- az oldatfázisban van és azok közé az ellenionok behatolhatnak, ha hidratált méretük megengedi. Végezetül nem szükséges, hogy az adszorbeált ionok teljes mértékben disszociált állapotban legyenek. Attól függően, hogy az egyes modellekre kifejtett energiatagok melyikét és milyen kombinációban használjuk, különböző izoterma-egyenleteket lehet levezetni és ezek mindegyike szerepel is az irodalomban. Az izotermaegyenletek részletes elemzése megtalálható az (5) közleményben.
Az elméletek tesztelését megnehezíti egyrészt az, hogy a kémiai és elektromos tagot csak együtt lehet mérni, melyekben a hibák kompenzálhatják egymást, másrészt az, hogy az elméletek 2-6 paramétert tartalmaznak, melyek segítségével gyakorlatilag mindegyik elmélet illeszthető a kísérleti adatokhoz. Az sem szerencsés körülmény, hogy az elméleti és kísérleti $\sigma(\log c)$ függvényeket szokás összehasonlítani azok deriváltjai helyett, mert ez az ábrázolás elfedi az adszorpcióban mutatkozó tényleges különbséget. Ezért az analízisnek az alábbi új módszerét vezetjük be. A 3. összefüggés alapján az izoterma formálisan megadható a következő alakban:

$$
\frac{\Gamma}{\Gamma_{o}-\Gamma}=K(\Gamma) a
$$

melyben $K(\Gamma)$ látszólagos egyensúlyi állandó, mely tartalmazza az adszorpciós rétegnek növekvő $\Gamma$-val az ideális állapottól való eltérését és $a$ a tenzid-elektrolit átlagos aktivitása az oldatban. $\ln K(\Gamma)=\ln K_{o}+f(\Gamma)+v_{\mathrm{o}}$, ahol $K_{o}$ a valódi egyensúlyi állandó $(\Gamma, f(\Gamma)$ az oldalsó kölcsönhatásokat reprezentálja az adszorpciós rétegben és $y_{o}$ a dimenzió nélküli elektromos potenciál. A kísérleti $K(\Gamma)$ értékekből az adszorpció szabadenergia-változását $\Delta G_{o}(\Gamma)=-R T \ln K(\Gamma)$ számolhatjuk $\Gamma$ függvényében.

A fenti értékelés előnye, hogy $K(\Gamma)$ közvetlenül számolható a kísérleti $\Gamma$ függvényekből egyetlen paraméter, a $\Gamma_{o}$ telítési adszorpció ismeretében.

$\Gamma_{\mathrm{o}}$ értéke is problematikus azonban. A kísérleti függvények $\Gamma$ (c) vízszintesbe hajló jellege azt sugallja, hogy a $\mathrm{cmc}$-nél az adszorpció eléri, vagy legalábbis megközelíti a telítési értéket, ezért a $c m c$-nél mért adszorpciót tekintik $\Gamma_{\mathrm{o}}$-nak. Az adszorpciós telítést azonban a tenzid kémiai potenciáljának függvényében kell elemezni, amely nem a koncentrációval, hanem a koncentráció logaritmusával arányos. Amint a 4. ábrán látható, a $c m c$-ig mért izotermák logaritmikus ábrázolásban meredeken növekvő tartományban vannak, vagyis semmi sem utal arra, hogy elérték volna maximális értéküket. Ezt erősíti meg az is, hogy nemionos tenzidek, alkoholok esetében az ionosokéhoz képest lényegesen nagyobb a maximális adszorbeált mennyiség, és az megegyezik a metilén csoport röntgen diffrakciós helyigényéből számolt értékkel.

A kísérleti izotermák értelmezése céljából a 3. egyenlet kémiai és elektromos tagjának leírására is új modellt vezetünk be. Az izotermák kezdeti gyorsuló adszorpciója magyarázható az adszorbeált molekulák közötti növekvő oldalsó kölcsönhatással, az izoterma jellegének megváltozása azonban nem, ugyanis ennek a kölcsönhatásnak a Frumkin izoterma szerint teljes borítottságig $(\Theta=1)$ növekedni kellene. Kimutatható, hogy kis adszorpcióknál energetikailag elönyösebb, ha az alkilláncok a vízfelszínnel párhuzamos és nem - amint azt számos sematikus ábrázolás sugallja - merőleges orientációban vannak. Ha az adszorpció eléri azt az értéket, hogy a fekvő láncok elkezdik átfedni egymást, akkor az oldalsó kölcsönhatás tovább már nem nö, hanem a szénhidrogénből a felszínen képződött „olajfilm” vastagsága 
növekszik. A további adszorbeált molekulák szénhidrogén lánca már ugyanolyan kölcsönhatási környezetbe kerül, vagyis az oldalsó kölcsönhatás már nem nő tovább. Egyszerúsített képpel ez úgy értelmezhetö, hogy a tenzid kezdetben oldat/levegö, majd bizonyos borítottság felett oldat/szénhidrogén határfelületen adszorbeálódik. Az olajfilm vastagságának $\Gamma_{\mathrm{s}}{ }^{*}$ feletti növekedését neutron diffrakciós- ${ }^{12}$, összegfrekvencia-keltési és ellipszometriás ${ }^{13}$ mérési módszerek, valamint Monte Carlo szimulációk ${ }^{14}$ is megerősítik. A fenti kép alapján az adszorpció hidrofób hajtóerejét az alábbi módon írjuk fel:

$$
\Delta \rho_{S}^{\prime}+f(\Theta)= \begin{cases}\Delta u_{S}^{0}+H \cdot\left(\Theta_{S}^{*}-\Theta_{S}\right) / \Theta_{S}^{*} & \text { if } \Theta_{S}<\Theta_{S}^{*} \\ \Delta u_{S}^{0} & \text { if } \Theta_{S}>\Theta_{S}^{*}\end{cases}
$$

melyben a $H$ kölcsönhatási paraméter a hidrofób kölcsönhatás különbsége a folyadék- és gázszerü adszorpciós állapot között.

Az adszorpció elektromos szabadenergiáját a módosított Goüy-Chapman modell alapján írjuk fel:

$$
\begin{gathered}
y_{0}=y_{d}+\sigma \frac{\delta}{\varepsilon_{0} \varepsilon_{S t}} \frac{e}{k T} \\
y_{d}=2 \sinh ^{-1}\left(\frac{e \sigma}{2 k T \varepsilon_{0} \varepsilon_{b} \kappa}\right)
\end{gathered}
$$

melyben $v_{o}$ és $v_{d}$ a dimenzió nélküli elektromos potenciál az adszorbeált ionok tömegközéppontjának, illetve a diffúz ionatmoszféra kezdetének (Stern potenciál) síkjában. $\delta$ a két sík távolsága, az a legkisebb távolság, melyre a hidratált ellenionok megközelíthetik az adszorbeált réteget. Az összefüggésben $e$ az elemi töltés, $\sigma$ a felületi töltéssürüség, $\varepsilon$ a dielektromos állandó vákuumban $(o)$, a Stern síkban $(S t)$, a tömbfázisban $(b)$ és $\kappa$ a Debye-Hückel féle reciprok ionatmoszféra vastagság.

A különböző elektromos modellek között lényegében $\ddot{a}$ definíciójában van az eltérés. A korábbi modellekben $\ddot{a}$-t a hidratált ellenion $\left(r_{h, c}\right)$ és a tenzid ionos fejcsoportja sugarának $\left(r_{h, \text { head }}\right)$ összegeként $\left(r_{h, c}+r_{h, \text { head }}\right)$ adták meg, nem véve figyelembe, hogy a hidratált ellenionok a felszínhez közelebb is mehetnek. Ez a definíció irreális hidrofób kölcsönhatást eredményez, mert az $v_{o}$ elektrosztatikus tag jelentős az adszorpció teljes szabadenergia-változásában, továbbá nem írja le, hogy a $\mathrm{K}, \mathrm{Rb}$ és Cs esetében az izoterma miért nem függ az ellenion minőségétől. Az elektromos modellt a 6. ábrán feltüntetett sémának megfelelően módosítottuk, mely alapján $\delta$-t az ionsugarak különbségeként $\left(\boldsymbol{r}_{\boldsymbol{h}, \boldsymbol{c}}-\boldsymbol{r}_{\boldsymbol{h}, \boldsymbol{h e a d}}\right)$ és nem az összegeként adjuk meg.
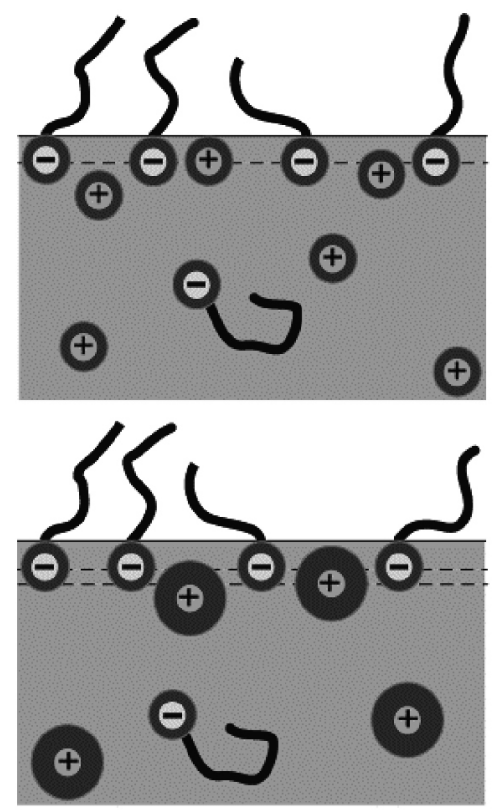

6. Ábra. Az adszorpciós réteg elektromos szerkezetének sémája különböző méretű ellenionok esetében. A felső ábrán a hidratált ellenion mérete kisebb, az alsón nagyobb a tenzidénél.

A 7. ábrán a kísérleti adatokból a 4. egyenlettel számolt standard szabadentalpia kémiai (hidrofób kölcsönhatásra eső) részét (a teljes szabadentalpiából az elektromos hozzájárulást kivonva) tüntettük fel az adszorbeált mennyiség függvényében. $\mathrm{Az}$ adszorpciós hajtóerő kezdetben nő (egyre negatívabb), majd 2,3 x10-10 mol.cm ${ }^{-2}$ körüli $\Gamma$ tartományt meghaladva konstanssá válik. A bemutatott adszorpciós modellnek megfelelően a $\Gamma \rightarrow 0$ extrapolációval az oldat/levegő, a konstans szakaszból pedig az oldat/szénhidrogén határfelületen történő adszorpció standard szabadentalpiája határozható meg.

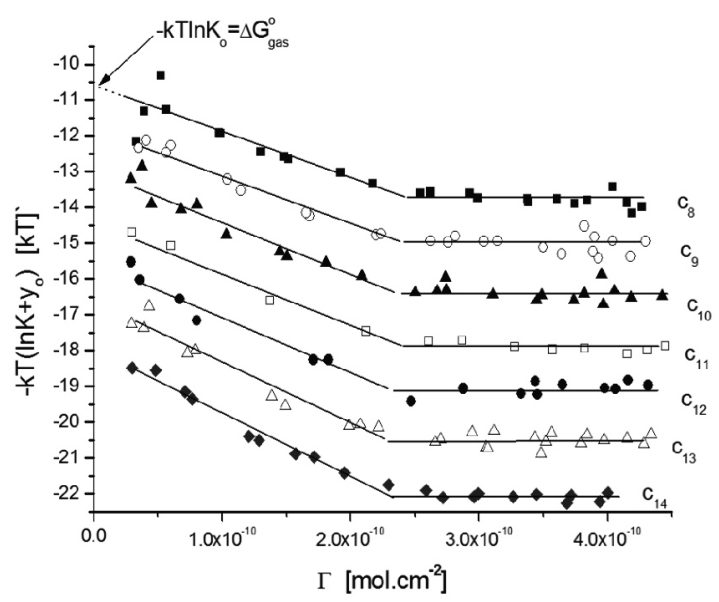

7. Ábra. A hidrofób kölcsönhatás változása a nátrium alkilszulfát homológok esetében az adszorbeált mennyiség növekedésével. 


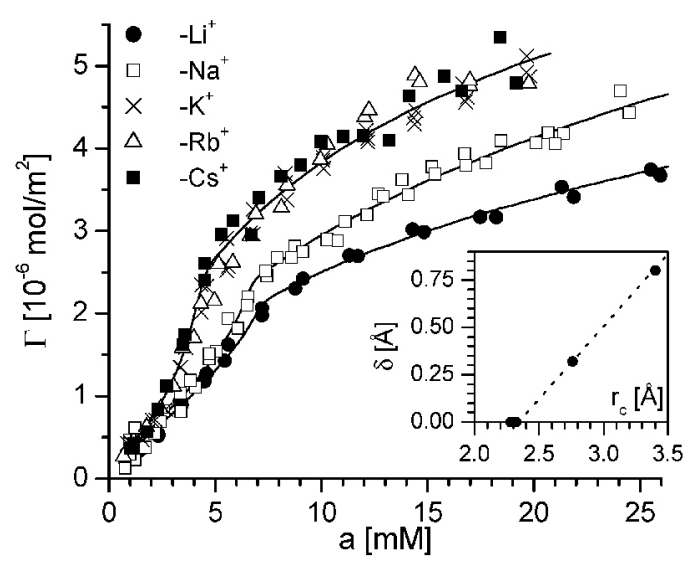

\section{Hivatkozások}

1. Phan, C.M.; Le, T.N.; Nguyen C.V.; Yusa, S. Langmuir 2013, 29, 4743-4749. https://doi.org/10.1021/la3046302

2. Dreger, E.E.; Keim, G.I.; Miles, G.T.; Sedlowsky, L.; Ross, J. Ind. Eng. Chem. 1944, 36, 610 .

https://doi.org/10.1021/ie50415a004

3. Mysels, K.J. Langmuir 1986, 2, 423-28. https://doi.org/10.1021/la00070a008

4. Gilányi, T.; Stergiopoulos, C.;Wolfram, E. Colloid Polym. Sci., 1976, 254, 1018. https://doi.org/10.1007/BF01516920

5. Gilányi, T.; Varga I.; Mészáros R. Physical Chemistry Chemical Physics 2004, 6, 4338-4346. https://doi.org/10.1039/B400958D

6. Lunkenheimer, K.; Czichocki, G.; Hirte, R.; Barzyk, W. Colloids Surf. 1995, 101, 187. https://doi.org/10.1016/0927-7757(95)03157-9

7. Hill, T.L. An Introduction to Statistical Thermodynamics, Addison-Wesley: Reading, MA, 1962. https://doi.org/10.1002/bbpc.19620660121

\section{Adsorption of ionic surfactants at air/solution interface}

The aim of this work is to analyse the correct measurements and evaluation of the surface tension data of ionic surfactant by means of the Gibbs adsorption equation.

Surfactant solutions always contain impurities, mainly alcohol and longer chain homologues, with surface activities significantly higher than that of the investigated surfactant. The general experience with surfactant solutions shows that bulk purification methods (e.g., recrystallization) do not provide sufficiently pure samples from the surface chemical point of view. Since the highly surface active impurities accumulate in the surface layer of the solution, sufficiently pure samples can be prepared by the repeated removal of the contaminated surface layer of the solution, which can be done either by foaming or by the repeated sucking off the surface. In the present work, surface purification was done by an improved version of the foam fractionation called the gas dispersion method resulting in "surface pure" adsorbed surfactant layers.

Experimental results are presented on the adsorption of sodium alkyl sulphate homologues $(n=8-14)$ at the air/solution interface. The measured surface-tension isotherms changed regularly, and the so-called odd/even
8. Ábra. A decilszulfát adszorpciós izotermái különböző alkáli ellenionok esetében. A kihúzott görbék az 5. és 6. egyenlettel számolt izotermák. A beszúrt ábrán a $\ddot{a}$ értékek szerepelnek az ellenion sugara függvényében.

A 8. ábrán a decilszulfát alkáli sók adszorpciós izotermái láthatók. Ezek mindegyike mutatja a kezdeti gyorsuló adszorpciót. Ugyanakkora aktivitásnál a Li, Na és $\mathrm{K}$ sók izotermái között nagymértékű eltérés van. Megállapítható, hogy a 6. ábrán bemutatott elektromos szerkezettel értelmezhető az ellenionok szerepe az ionos tenzidek adszorpciójában. Az elméleti (kihúzott görbék) izotermák jól egyeznek a kísérleti adatokkal.

8. Davies, J. T. Proc. R. Soc. London, Ser. A 1951, 208, 224. https://doi.org/10.1098/rspa.1951.0156

9. Borwankar, R. P.; Wasan, D. T. Chem. Eng. Sci. 1986, 1, 199. https://doi.org/10.1016/0009-2509(86)85217-4

10. Warszynski, P.; Barzyk, W.; Lunkenheimer, K.; Fruhner, H. J. Phys. Chem. B 1998, 102, 10948. https://doi.org/10.1021/jp983901r

11. Kalinin, V. V.; Radke, C. J. Colloid Surface A 1996, 114, 337. https://doi.org/10.1016/0927-7757(96)03592-3

12. Lee, E. M.; Thomas, R. K.; Penfold, J.; Ward, R. C.: $J$. Phys. Chem. 1989, 93, 381.

https://doi.org/10.1021/j100338a073

13. Bell, G. R.; Manning Benson, S.; Bain, C. D.: J. Phys. Chem. B. 1998, 102, 218. https://doi.org/10.1021/jp972647k

14. Jedlovszky, P., Varga, I.; Gilányi, T.: J. Chem. Phys. 2004, 120, 11839. https://doi.org/10.1063/1.1753255

effect could not be observed. The discrepancy with the earlier investigations was interpreted in terms of the purity of the surfactants.

The surface-tension isotherms of the surfactant solutions or their equivalent adsorption isotherms are usually interpreted in terms of a surface equation of state, which are always based on a priori model assumptions giving rise to several fitting parameters (between two and six). Unfortunately, different models can usually provide similar quality fits to the same experimental data; thus, even if a given model describes the experimental data, there is always the question of whether its success is indeed due to the correctness of the underlying physical assumptions or whether this is due to the fortunate interplay of the fitting parameters. A possible solution to this problem could be a model-independent evaluation of the experimental data.

We presented a novel approach for the analysis of the surface tension isotherms, which is based on the calculation of the model-independent total adsorption driving force in the function of the adsorbed amount $(\Gamma)$. Formally, the well-known Langmuir isotherm was used with $K(\Gamma)$ apparent equilibrium constant, which is related to the actual 
adsorption driving force at any given adsorbed amount. The major advantage of this method is that the total free energy change of adsorption can be directly calculated from the adsorption isotherms as a function of the adsorbed amount instead of fitting an isotherm equation to the adsorption data. Furthermore, the non-electrostatic adsorption driving force $\left(\Delta G_{o}(\Gamma)-y_{0}\right)$ may also be determined by means of an appropriate model for the electrical contribution $\left(y_{0}\right)$. The $\left(\Delta G_{o}(\Gamma)-y_{0}\right)$ vs $\Gamma$ functions are even more informative than the adsorption isotherms themselves and provide an opportunity to develop more exact theoretical isotherm equations. The new analysis of the adsorption isotherm of all investigated surfactant homologues revealed that the hydrophobic driving force of the adsorption first increases with increasing $\Gamma$, and then becomes independent of $\Gamma$. This peculiar behaviour was interpreted by the formation of a thin liquid-like alkane film in the adsorbed layer once a critical adsorbed amount is exceeded. Independent experimental results (neutron reflection, ellipsometry, sum-frequency generation spectroscopy) as well as alkane solubility data seem to support the existence of saturation-type hydrophobic driving-force functions.
Experimental results are presented on the counter ion dependence of the adsorption of alkali ( $\mathrm{Li}, \mathrm{Na}, \mathrm{K}, \mathrm{Rb}$ and $\mathrm{Cs}$ ) decyl sulphates at the air/solution interface. The adsorption isotherms calculated from equilibrium surface tension vs. concentration data by means of the Gibbs equation show significant counter ion dependence. We propose a theoretical model based on the Goüy-Chapman-Stern theory for the description of the ionic surfactant adsorption at the air/solution interface. The model is based on the physical picture that the counter ions can enter among the surfactant head groups if the hydrated counter ion size is smaller than that of the head groups. In this case, the diffuse part of the double layer starts from the plane of the head groups. If the size of the counter ions is larger than the size of the head groups then the closest approach of the counter ions in the diffuse layer is assumed to be equal to the difference between the size of the hydrated surfactant head group and that of the counter ion. The model correctly describes the counter ion dependence of the adsorption isotherms measured for the alkali alkyl sulphates. The results indicate that the fine structure of the double layer can play an important role in the counter ion specificity of ionic surfactant adsorption. 